\title{
THE SYSTEM DIOPSIDE - FORSTERITE - ENSTATITE AT 5.1 GPa: A TERNARY MODEL FOR MELTING OF THE MANTLE ${ }^{\mathbb{I}}$
}

\author{
YI-HUA WENG \\ Department of Geosciences, The University of Texas at Dallas, P.O. Box 830688, Richardson, Texas 75083-0688, U.S.A. \\ DEAN C. PRESNALL ${ }^{\S}$ \\ Geophysical Laboratory, Carnegie Institution of Washington, 5251 Broad Branch Road, N.W., \\ Washington, D.C. 20015-1305, and Department of Geosciences, The University of Texas at Dallas, P.O. Box 830688, \\ Richardson, Texas 75083-0688, U.S.A.
}

\begin{abstract}
Data determined using a multianvil press are given for liquidus phase relations in the system diopside - forsterite - enstatite $\left(\mathrm{CaMgSi}_{2} \mathrm{O}_{6}-\mathrm{Mg}_{2} \mathrm{SiO}_{4}-\mathrm{MgSiO}_{3}\right)$ and extend for a limited distance into the larger ternary system diopside - forsterite - quartz at $5.1 \mathrm{GPa}$. In the system diopside-enstatite, which cuts across the system diopside - forsterite - quartz and divides it into two smaller ternary systems, the peritectic between clinopyroxene and orthopyroxene occurs at $\mathrm{Di}_{43} \mathrm{En}_{57}$ and is defined by the reaction $100 \mathrm{cpx}=64 \mathrm{opx}+36$ liq. An azeotropic minimum occurs on the clinopyroxene liquidus at $\mathrm{Di}_{67} \mathrm{En}_{33}$. In the ternary system diopside - forsterite - enstatite, a peritectic occurs at $\mathrm{Di}_{43} \mathrm{Fo}_{46} \mathrm{Qtz}_{11}$ and is defined by the reaction $69 \mathrm{opx}+31 \mathrm{liq}=95 \mathrm{cpx}+5 \mathrm{fo}$ (wt.\%). These ternary phase relations can be used to model three important aspects of the volatile-free phase relations and melting behavior of natural peridotite with a high degree of accuracy. (1) Olivine, orthopyroxene, and clinopyroxene occur at the solidus at $2 \mathrm{GPa}$, but orthopyroxene is absent at the solidus at $5.1 \mathrm{GPa}$. (2) During equilibrium melting at 5.1 GPa, orthopyroxene appears just above the solidus and then disappears again at higher temperatures. At both 2 and $5.1 \mathrm{GPa}$, the proportions of phases in the ternary system at various degrees of melting are close to the proportions observed in the melting of natural peridotite by Walter (1998). (3) As pressure increases, $\mathrm{MgO}$ increases and $\mathrm{SiO}_{2}$ decreases in initial melts.
\end{abstract}

Keywords: mantle, melting, phase relations, peridotite, diopside, forsterite, enstatite.

\section{SOMMAIRE}

Nous présentons des données sur les relations de phases sur le liquidus pour le système diopside - forstérite - enstatite $\left(\mathrm{CaMgSi}_{2} \mathrm{O}_{6}-\mathrm{Mg}_{2} \mathrm{SiO}_{4}-\mathrm{MgSiO}_{3}\right)$, avec extension limitée dans le système ternaire plus complet, diopside - forstérite - quartz; elles ont été déterminées à $5.1 \mathrm{GPa}$ avec un appareil à enclumes multiples. Dans le système diopside-enstatite, qui recoupe le système diopside - forstérite - quartz et le subdivise en deux systèmes ternaires plus petits, la relation péritectique entre clinopyroxène et orthopyroxène se situe au point $\mathrm{Di}_{43} \mathrm{En}_{57}$; cette réaction serait $100 \mathrm{cpx}=64 \mathrm{opx}+36$ liq. Un minimum azéotrope se trouve sur la partie du liquidus où le clinopyroxène est présent, à $\mathrm{Di}_{67} \mathrm{En}_{33}$. Dans le système ternaire diopside - forstérite enstatite, une relation péritectique a lieu à $\mathrm{Di}_{43} \mathrm{Fo}_{46} \mathrm{Qtz} \mathrm{z}_{11}$; cette réaction serait $69 \mathrm{opx}+31 \mathrm{liq}=95 \mathrm{cpx}+5$ fo (proportions pondérales). Nous nous servons de ces relations de phases ternaires pour proposer un modèle de trois aspects importants des relations en l'absence d'une phase volatile et du mode de fusion de péridotites naturelles avec un degré élevé de justesse. (1) Olivine, orthopyroxène, et clinopyroxène se trouvent sur le solidus à $2 \mathrm{GPa}$, mais l'orthopyroxène est absent au solidus à $5.1 \mathrm{GPa}$. (2) Au cours d'une fusion à l'équilibre à $5.1 \mathrm{GPa}$, l'orthopyroxène apparait à une température légèrement supérieure au solidus et disparait de nouveau à une température plus élevée. Aux deux pressions, 2 et $5.1 \mathrm{GPa}$, la proportion des phases dans le système ternaire à divers taux de fusion se rapproche des proportions observées au cours de la fusion de péridotite naturelle par Walter (1998). (3) A mesure qu'augmente la pression, la proportion de $\mathrm{MgO}$ augmente et celle de $\mathrm{SiO}_{2}$ diminue dans le liquide initial.

(Traduit par la Rédaction)

Mots-clés: manteau, fusion, relations de phases, péridotite, diopside, forstérite, enstatite.

II Contribution No. 920, Department of Geosciences, University of Texas at Dallas.

§E-mail address: presnall@gl.ciw.edu 


\section{INTRODUCTION}

The ternary system diopside - forsterite - enstatite $\left(\mathrm{CaMgSi}_{2} \mathrm{O}_{6}-\mathrm{Mg}_{2} \mathrm{SiO}_{4}-\mathrm{MgSiO}_{3}\right)$ shows phase relations among the three most important minerals of the upper mantle and has long been employed as a basis for modeling the generation and crystallization of basaltic magmas and the compositional trends of their residues (Bowen 1914, 1928, Kushiro 1968, 1969, 1972a, b, 1975, Carter 1970, Dick \& Fisher 1984, Dick et al. 1984). This system also has relevance to komatiitic magmas, which have generally been considered to be generated at substantially greater depths than those relevant to the generation of basaltic magmas (Scarfe \& Takahashi 1986, Herzberg 1992, Herzberg \& O'Hara 1998, Gudfinnsson \& Presnall 1996). Also, it has been argued that the low-temperature garnet peridotite xenoliths from southern Africa may be residues produced by the removal of komatiitic liquids at pressures above 5 GPa (Boyd 1987, Boyd \& Mertzman 1987, Canil 1992). However, Parman et al. (1997) proposed a moderate-pressure, hydrous origin for komatiites. In order to understand these deep melting processes, it is important to know the phase relations of mafic systems at pressures greater than $4 \mathrm{GPa}$, just as experimental studies have clarified many aspects of the origin of basaltic magmas at lower pressures. To this end, we present a determination of liquidus phase relations in the ternary system diopside - forsterite - enstatite at 5.1 GPa.

\section{Experimental and Analytical Methods}

All experiments were conducted with a 1500-tonne multianvil press designed and built at the University of Texas at Dallas. The design includes an overhead ram, a split-cylinder guideblock, and anvil drivers free to rotate and self-align within the cylindrical cavity. The sample assembly is the same as that shown by Dalton \&

'LALE I COMPOSIIIOYS OF STARIIAG MLX'L'RES*

\begin{tabular}{|c|c|c|c|c|}
\hline & $\mathrm{CaMH}_{5} \mathrm{Si}_{\bar{x}} \mathrm{O}$ & MiLSiO. & $\mathrm{SiD}_{3}$ & $\mathrm{MgSiO}_{3}$ \\
\hline CME-] & $26 ? 6$ & 61.12 & $114 \mathrm{t}$ & \\
\hline CMS-5 & 35.41 & 41.12 & 2348 & \\
\hline C.MS-6 & 5500 & 3500 & 10.00 & \\
\hline $435-7$ & 57.00 & 3300 & & \\
\hline$C \mathrm{LS}-8$ & 47.00 & & & 53.00 \\
\hline CWS-9 & 3500 & 37.90 & 5.00 & \\
\hline C.MS-10 & 2000 & 59.00 & 21.00 & \\
\hline $6 \times 5-72$ & 1400 & 72.00 & 14.00 & \\
\hline CWS-13 & 2].05 & 57.42 & 21.53 & \\
\hline CMS-14 & 20.50 & & & 79.50 \\
\hline CVS-15 & 67.00 & & & $3 \div .60$ \\
\hline CWS-16 & 4200 & 48,00 & 10.00 & \\
\hline $643-17$ & 44,00 & 45. & 13.00 & \\
\hline 6) 18 & 53.50 & & & 16.50 \\
\hline CMIS-19 & 46.00 & 44.00 & 10.00 & \\
\hline
\end{tabular}

* opprossed it wt. $\%$
Presnall (1998a). A semi-sintered $18 \mathrm{~mm} \mathrm{MgO-}$ $5 \% \mathrm{Cr}_{2} \mathrm{O}_{3}$ octahedron was used as the pressure medium enclosed within WC cubes with $11 \mathrm{~mm}$ truncations. Heating was provided by a stepped graphite furnace, which gives a temperature gradient of about $20^{\circ} \mathrm{C}$ across the capsule, as determined by experiments on the melting of diopside.

The pressure calibration curve used in this study (Fig. 1) is a straight line defined by the quartz-coesite transition (Hemingway et al. 1998) and the garnetperovskite transition for $\mathrm{CaGeO}_{3}$ (Susaki et al. 1985). Extrapolation of this line to zero oil pressure gives a slightly positive value for pressure on the sample. Zero oil pressure at zero load has not been used in defining the curve because the weight of the large overhead ram and guideblock assembly add a small but undetermined pressure in addition to the oil pressure. Because we have used the quartz-coesite curve of Hemingway et al. (1998) rather than that of Bohlen \& Boettcher (1982) used earlier in this laboratory, our new calibration curve (Fig. 1) gives slightly higher pressures for a given load at pressures less than $6 \mathrm{GPa}$. Also, we have based the new calibration curve on a new point for the quartzcoesite transition at $1200^{\circ} \mathrm{C}$ (Fig. 1), with results that are consistent, within limits of experimental error, with our previous point at $1100^{\circ} \mathrm{C}$. Conversion of pressures in previous publications from this laboratory (Dalton \& Presnall 1997, 1998a, b) to the current calibration curve can be made using the equation, $\mathrm{P}_{\text {new }}(\mathrm{GPa})=0.932 \mathrm{P}_{\text {old }}$ $(\mathrm{GPa})+0.405$. The maximum difference in the $3-7 \mathrm{GPa}$ range is $0.2 \mathrm{GPa}$.

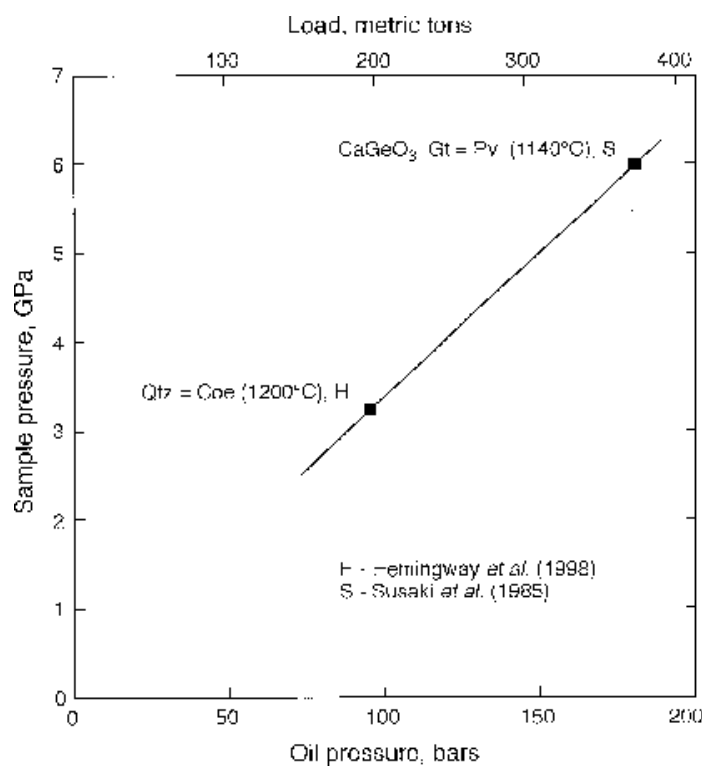

FIG. 1. Pressure calibration curve. Abbreviations are: Gt, garnet; Pv, perovskite; Qtz, quartz; Coe, coesite. 
Bulk compositions of starting mixtures used in the experiments are listed in Table 1. Mixtures were prepared by mixing reagent-grade $\mathrm{SiO}_{2}, \mathrm{MgO}$, and $\mathrm{CaCO}_{3}$ powders previously dried at 1200,1250 , and $450^{\circ} \mathrm{C}$, respectively. Each mixture, prepared as a 5-gram batch, was fired at $1500-1600^{\circ} \mathrm{C}$ for 2 hours and then ground to a fine powder $(<5 \mu \mathrm{m})$. Starting mixtures were loaded into Pt capsules, which were closed by folding immediately after being dried at $1000^{\circ} \mathrm{C}$. The entire octahedron assembly with the sample enclosed was fired at $1000^{\circ} \mathrm{C}$ for 1 hour in nitrogen immediately before each experiment to remove any traces of water. Samples were slowly pressurized to $5.1 \mathrm{GPa}$, heated at $200^{\circ} \mathrm{C}$ /minute to the desired temperature, held within $\pm 2{ }^{\circ} \mathrm{C}$ of the desired temperature by a Eurotherm $818 \mathrm{P}$ controller, and quenched by turning off the power supply. Temperatures were measured by a W3Re-W26Re thermocouple with no correction for the effect of pressure on the thermocouple emf. Reproducibility of temperature and pressure is approximately $\pm 20^{\circ} \mathrm{C}$ and $\pm 0.1 \mathrm{GPa}$.

Phases were identified in polished sections using both optical microscopy and back-scattered electron imaging with a JEOL 8600 electron microprobe at the University of Texas at Dallas. Phase compositions were determined by wavelength-dispersion analysis using a $10 \mathrm{nA}$ beam and $15 \mathrm{keV}$ accelerating voltage. Crystalline phases were analyzed with a focused beam. For quenched liquids, which were totally transformed into quenched crystals, a defocused beam 5-15 $\mu \mathrm{m}$ across was used. X-ray counts were accumulated until a standard deviation of $0.1 \%$ counting statistics or 40 -second counting time was achieved for all elements in all phases. The ZAF correction program was applied to all results.

\section{Attainment of EQuilibrium}

Experiments were held at temperature for 20 to 31 minutes (Table 2). A combination of previous experience and one new reversal experiment was used as a guide to run times appropriate for achieving equilibrium. For enstatite melting, Presnall et al. (1973) found at 2.5 $\mathrm{GPa}$ that the melting temperature remains unchanged for run durations ranging from 10 minutes to 48 hours. All of the run temperatures in this study (Table 2) are at least $50^{\circ} \mathrm{C}$ higher than the melting temperature of $1787^{\circ} \mathrm{C}$ at $2.5 \mathrm{GPa}$. On the assumption that compositional effects are small, orthopyroxene-liquid equilibrium should occur in less than 10 minutes. For clinopyroxene melting, our experience in calibrating thermocouples against the melting point of pure diopside at $1 \mathrm{~atm}$. has shown that run times of 10 minutes are more than is needed. The experiments in this study are all at least $450^{\circ} \mathrm{C}$ higher, where the time required for equilibrium would be much less than 10 minutes. We find quench crystals of forsterite in runs ranging down to the lowest temperature used $\left(1850^{\circ} \mathrm{C}\right.$, run 134$)$. Therefore, we believe that our run times of 20-30 min- utes are adequate for equilibrium crystallization of forsterite. To test the time for equilibrium melting of both forsterite and clinopyroxene, we have done one uptemperature reversal experiment on composition CMAS-7. The initial conditions were $1810^{\circ} \mathrm{C}$ for 20 minutes to produce a completely crystalline mixture of forsterite and clinopyroxene. The temperature was then raised to $1940^{\circ} \mathrm{C}$ and held for another 20 minutes without taking the sample out of the press. The result was all quench crystals, a successful reversal.

\section{The System Diopside-Enstatite}

Phase relations for the system diopside-enstatite are shown in Figure 2 and are based on experimental results given in Table 2 . The melting temperature of pure diopside, $1886^{\circ} \mathrm{C}$, is an average of the data of Boyd \& England (1963) and Williams \& Kennedy (1969). This average deviates from each curve by $24^{\circ} \mathrm{C}$, which is only slightly greater than the experimental uncertainty. The melting point of pure enstatite, $1965^{\circ} \mathrm{C}$, is calculated from the equation of Presnall \& Gasparik (1990) and is within experimental error of the determination of Boyd et al. (1964).

The clinopyroxene liquidus (Fig. 2) is very flat. Although the temperature difference between the

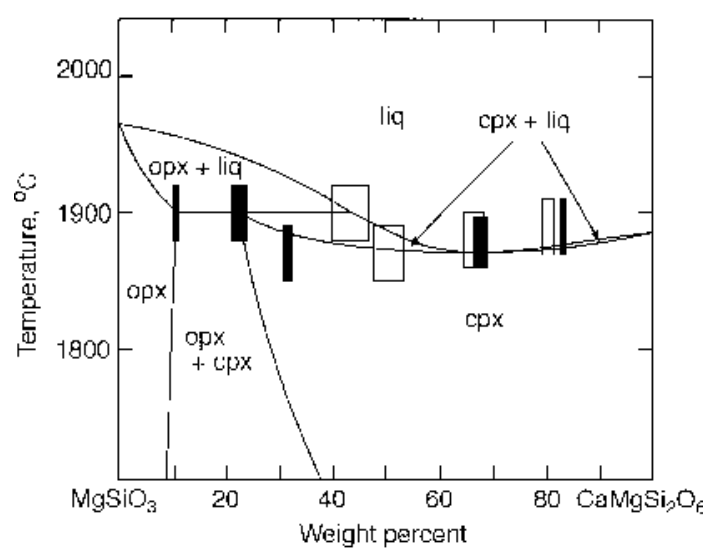

FIG. 2. Phase relations in the $\mathrm{MgSiO}_{3}-\mathrm{CaMgSi}_{2} \mathrm{O}_{6}$ system at $5.1 \mathrm{GPa}$. Analyzed phase-compositions are shown for liquids (open rectangles) and coexisting pyroxenes (filled rectangles). The width of the rectangles is two standard errors of the mean, and the height is the estimated uncertainty in temperature, $\pm 20^{\circ} \mathrm{C}$. The height of one filled rectangle has been reduced to reveal the uncertainty of the coexisting liquid. The melting point of $\mathrm{MgSiO}_{3}$ is taken from the equation of Presnall \& Gasparik (1990), and is within the uncertainty of the value determined by Boyd et al. (1964). The melting point of $\mathrm{CaMgSi}_{2} \mathrm{O}_{6}$ is the average of the values given by Boyd \& England (1963) and Williams \& Kennedy (1969). Abbreviations are: opx, orthopyroxene; cpx, clinopyroxene; liq, liquid. 
TABLE 2 EXPERIMENTAL AVD ANALYTICAL DATA"

$\begin{array}{llllllll}\mathrm{SiO}_{2} & \mathrm{MgO} & \mathrm{CaO} & \text { Total } & \mathrm{Di} & \mathrm{F}_{0} & \mathrm{Qtz}\end{array}$

Diopside - Enstatite

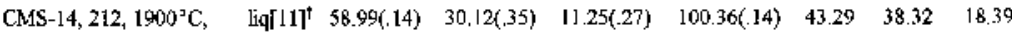

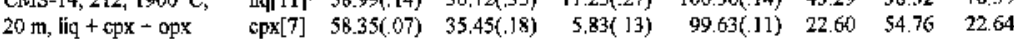
opx[5] 5B.70(.08) $37.59(18) \quad 2.81(04) \quad 99.50(13) \quad 10.9] \quad 63.10 \quad 26.00$

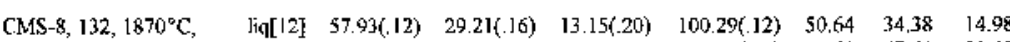

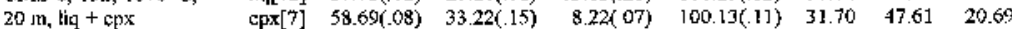

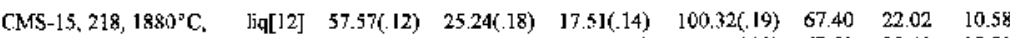

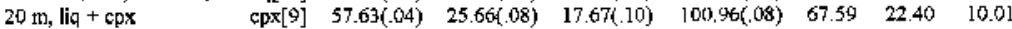

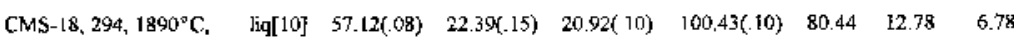

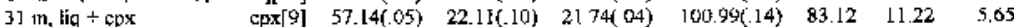

Fursterite - Diopside -. Siljca

\begin{tabular}{|c|c|c|c|c|c|c|c|c|}
\hline \multirow{3}{*}{$\begin{array}{l}\mathrm{CMS}=10,153,1900^{\circ} \mathrm{C} \\
20 \mathrm{~m}, \operatorname{liq}+\mathrm{fo}+\mathrm{cpx}+\mathrm{qpx}\end{array}$} & $f 0[4]$ & $\$ 264(.01)$ & $57.35(.12)$ & $0.34(01)$ & $100,33(.14)$ & 1.31 & 99.34 & -0.55 \\
\hline & $\mathrm{cpx}[-4]$ & $58.56(.23)$ & $35.47(.03)$ & 3. $7 G(06)$ & $99.79(28)$ & 22.29 & 54.80 & 22.91 \\
\hline & opx[4] & $59.33(06)$ & $37.75(.77)$ & $2.92(09)$ & $160.00(27)$ & $11.2 \mathrm{~B}$ & 62.22 & 26.50 \\
\hline \multirow{3}{*}{$\begin{array}{l}\text { CMAS-12, J63, } 1920=\mathrm{C} \\
20 \mathrm{~m} \text {, liq }+ \text { fan }+\mathrm{apx}\end{array}$} & $\operatorname{liq}_{4}[14]$ & $55.15(.50)$ & $39.80(.59)$ & $6.44(.18)$ & $100.39(06)$ & 24.77 & 59.41 & 15.82 \\
\hline & fo[s] & $43.56(.04)$ & $56.65(.15)$ & $0,27(.02)$ & $100.48(14)$ & 1.04 & 98,06 & 0.90 \\
\hline & $a p x[7]$ & $50.69(.06)$ & $38.68(.13)$ & $1.55(.15)$ & $100,42(16)$ & 5.93 & 64.97 & 29.10 \\
\hline \multirow{3}{*}{$\begin{array}{l}\text { CWS-1, } 164,1910^{\circ} \mathrm{C} \text {, } \\
20 \text { mil } 1 \mathrm{iq}+\mathrm{to}+\mathrm{opx}\end{array}$} & $\operatorname{lig}[24]$ & $54.89(60)$ & $37.22(.61)$ & $7.67(.51)$ & $99.72(09)$ & 29,69 & 55.46 & 14.85 \\
\hline & to $[\%]$ & $43.53(04)$ & $56.79(03)$ & $0.25(01)$ & $100.5 T(06)$ & 0.96 & 98.24 & 0.80 \\
\hline & $0 \mathrm{ps}$ [石] & $60.63(.05)$ & $38.64(.16)$ & $1.56(.13)$ & $100.83(09)$ & 5.97 & 64,94 & 29.08 \\
\hline \multirow{3}{*}{$\begin{array}{l}\text { CMS-13, 204, } 1995^{\circ} \mathrm{C} \\
20 \mathrm{~m}, \mathrm{liq}+\mathrm{cpx}+\mathrm{ops}\end{array}$} & $\operatorname{lig}[11]$ & $54.88(.34)$ & $33.25(.19)$ & $11.27(.76)$ & $99.40(18)$ & 43.79 & 44,16 & 12.06 \\
\hline & $\operatorname{cpx}[5]$ & $57.68(.11)$ & $35.54(.15)$ & $5.75(.13)$ & $98.97(17)$ & 22.44 & 55,39 & 22.18 \\
\hline & $\operatorname{ppx}[5]$ & $58.58(.05)$ & $38] 3(, 21)$ & $2.84(.03)$ & $99.55(13)$ & 13.02 & 63.27 & 25.71 \\
\hline \multirow{3}{*}{$\begin{array}{l}\text { CMS-5, } 106,1890^{\circ} \mathrm{C} \\
20 \mathrm{~m}, 1 \mathrm{j} q+\mathrm{opx}+0 \mathrm{pt}\end{array}$} & $\operatorname{liq}[17]$ & $64.15(.56)$ & $23.96(.65)$ & $12,37(, 12)$ & $99.48(.10)$ & 44.14 & 27.70 & 28.16 \\
\hline & $\cos [7]$ & $58.43(07)$ & $3520(14)$ & $5.93(.08)$ & $99.56(.19)$ & 23.00 & 54.24 & 22.76 \\
\hline & 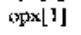 & 59.14 & 3737 & 2.84 & 99.35 & 1104 & 62.06 & 26.90 \\
\hline \multirow{3}{*}{$\begin{array}{l}\text { CMS-5, 10B, } 1870^{\circ} \mathrm{C} \\
205 \mathrm{~m}, \mathrm{liq}+\mathrm{opx}+\mathrm{opx}\end{array}$} & $\operatorname{liq}[16]$ & $64,38(61)$ & $22.96(.78)$ & $11.6 .3(11)$ & $77(53)$ & 45.38 & 25.75 & 28.87 \\
\hline & $\mathrm{cpx}[6]$ & $58.50(04)$ & $34.81(09)$ & $6.30(.07)$ & $9961(10)$ & 24.12 & 53.06 & 22.52 \\
\hline & $0 p x[1]$ & 59.38 & 37.52 & 2.82 & 99.72 & 10.92 & 62.12 & 26.96 \\
\hline \multirow{2}{*}{$\begin{array}{l}\text { CWB- } 16,2 \mathrm{t} \text {, } 1900^{\circ} \mathrm{C} \\
20 \mathrm{~m}, \mathrm{liq}+\mathrm{fo}+\mathrm{qps}\end{array}$} & $\operatorname{liq}: 31]$ & $54.22(13)$ & $34,31,39)$ & $1 \mid .73(.28)$ & $10025(12)$ & 45.18 & 4.50 .5 & 9.77 \\
\hline & $\operatorname{cpx}[6]$ & $58.03(24)$ & $34.57(27)$ & $7.11(.30)$ & $99.7](20)$ & 27.96 & 51.06 & 21.08 \\
\hline \multirow{2}{*}{$\begin{array}{l}\text { CMS }-17,745,1930 \%, \\
30 \mathrm{~m}, \mathrm{lic} \text { । } \mathrm{gpx}\end{array}$} & $\operatorname{liq}[24]$ & $53.43(.99)$ & $33.74(33)$ & $11.95(\mathrm{zO})$ & $99.140 .08)$ & 46.55 & 44.28 & 9.17 \\
\hline & $\operatorname{cpx}[9]$ & $57,25(07)$ & $53,99(.21)$ & $7.96(26)$ & $9918(11)$ & 30.99 & 49.75 & 19.26 \\
\hline \multirow{2}{*}{$\begin{array}{l}\text { CMS-19, } 332,1895^{\circ} \mathrm{C} \\
30 \mathrm{~m}, \mathrm{lq}+\text { to }+\mathrm{ppx}\end{array}$} & $\operatorname{liq}[20]$ & $53.07(53)$ & $32.61(.64)$ & $14.08(.26)$ & $99.75(15)$ & 54.51 & 79.75 & 6.15 \\
\hline & $\operatorname{cps}[?]$ & $57.82(06)$ & $30.71(.14)$ & $11.69(10)$ & $10022(17)$ & 45.05 & 39.85 & 16. I I \\
\hline \multirow{3}{*}{$\begin{array}{l}\text { CMS-19, } 737,1910^{\circ} \mathrm{C} \\
30 \mathrm{~m}, \mathrm{liq}+\mathrm{fo}+\mathrm{ppk}\end{array}$} & $\operatorname{liq}[19]$ & $52,13(, 39)$ & $32,28(42)$ & $14.45(.22)$ & $98.86(08)$ & 57.00 & 39.41 & 4.59 \\
\hline & $f o[3]$ & $4160(15)$ & $56.84(.15)$ & $0.58(06)$ & $9902(W)$ & 2.26 & 99.45 & $-1.7\rfloor$ \\
\hline & $\operatorname{cpx}[30]$ & $56.47(11)$ & $29,56(.23)$ & $1308(27)$ & $09.11(13)$ & 50.97 & 35.50 & 13.54 \\
\hline \multirow{3}{*}{$\begin{array}{l}\text { CMS-9, 134, } 1850^{\circ} \mathrm{C} . \\
20 \mathrm{~m} \text {, liq }+ \text { fo }+ \text { cps }\end{array}$} & $\operatorname{lig}[14]$ & $51,6 T(5 T)$ & $3161(87)$ & $16.07(.50)$ & $99.35(21)$ & 62.47 & 3.3 .24 & 2,30 \\
\hline & $f_{0}[1]$ & 42.50 & 55.89 & $0,8.7$ & 9922 & 3.23 & 97.26 & -0.50 \\
\hline & $\operatorname{cps} 5$ ! & $56.54(08)$ & $25.05(21)$ & $7,7,65(, 22)$ & $9931(11)$ & 71.60 & 19.79 & 8.61 \\
\hline \multirow{3}{*}{$\begin{array}{l}\mathrm{CHS}-7,117,1870^{\circ} \mathrm{C} \\
20 \mathrm{~m}, \mathrm{liq}+\mathrm{fo}-\mathrm{px}\end{array}$} & $\operatorname{lig}[28]$ & $50.80(47)$ & $30.23(47)$ & $17.52(.28)$ & $9853(24)$ & 68.65 & 31.24 & 0.11 \\
\hline & $f \circ[6]$ & $43.59(09)$ & $55.43(13)$ & $1.07(01)$ & $1000908)$ & 4.13 & 95.32 & 0.56 \\
\hline & $\operatorname{cpx}[14]$ & $\$ 6.61(10)$ & $22.86(06)$ & $20,36(.09)$ & $9084(13)$ & 78.76 & 14.38 & 6.86 \\
\hline
\end{tabular}

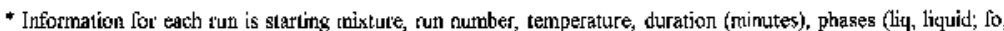
forsterite; cpx, clinopyroxene; opk, orthopyroxene). All valuos in wh. \%.

* Vumber of spots analyzed in square brackets, one stardard error of the mean in jarentheses. 
clinopyroxene liquidus and the solidus is within experimental uncertainty, a temperature minimum is placed at $\mathrm{Di}_{67} \mathrm{En}_{33}$ on the basis of (1) the nearly identical compositions of the starting mixture and the coexisting clinopyroxene and liquid for run 218 (Table 2), and (2) experiments on two bulk compositions lying on opposite sides of the temperature minimum that show liquid compositions closer to the minimum than the coexisting clinopyroxene (runs 132 and 294, Table 2). The location of this minimum is essentially identical to that of the minimum found by Kushiro (1969) at $2 \mathrm{GPa}$. The reaction at the cpx - opx - liq peritectic (Fig. 2) is 100 $\mathrm{cpx}=64 \mathrm{opx}+36 \mathrm{liq}$, and the peritectic point occurs at $\mathrm{Di}_{43} \mathrm{En}_{57}$. Di and En are used throughout to indicate pure diopside $\left(\mathrm{CaMgSi}_{2} \mathrm{O}_{6}\right)$ and enstatite $\left(\mathrm{MgSiO}_{3}\right)$. Solid solutions are indicated by cpx and opx. Phase and endmember proportions are expressed by weight.

At the solidus, orthopyroxene contains 10.9 wt. $\%$ $\mathrm{CaMgSi}_{2} \mathrm{O}_{6}$, a value very close to that determined at 2 $\mathrm{GPa}\left(10\right.$ wt. $\% \mathrm{CaMgSi}_{2} \mathrm{O}_{6}$ ) by Kushiro (1969) and at 3 GPa (8.5 wt.\% $\mathrm{CaMgSi}_{2} \mathrm{O}_{6}$ ) by Davis \& Boyd (1966). Gasparik (1990) thermodynamically modeled pyroxene phase-relations and showed pigeonite and diopsidic clinopyroxene solid solutions merged as a single clinopyroxene phase at pressures greater than $2 \mathrm{GPa}$. Gasparik (1996) also studied solidus phase-relations on the Di-En join at pressures from 7 to $22.4 \mathrm{GPa}$. At 5.1 $\mathrm{GPa}$, compositions of the solidus clinopyroxene, the

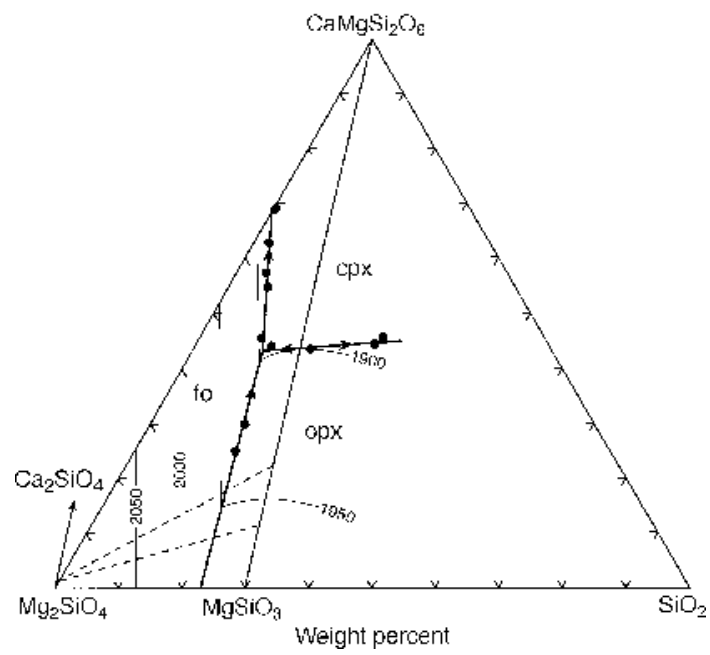

FIG. 3. Liquidus phase-relations for the system diopside forsterite - silica at $5.1 \mathrm{GPa}$. Heavy lines are boundary lines, and light lines are liquidus isotherms in ${ }^{\circ} \mathrm{C}$. The dashed triangle shows compositions of crystalline phases in equilibrium with liquid at the clinopyroxene - forsterite - orthopyroxene peritectic. Data points are liquid compositions given in Table 2. Abbreviations are as in Figure 2 except that fo is forsterite. peritectic point, and the azeotropic minimum from this study are all consistent with extrapolation of his data.

\section{The System Diopside - Forsterite - Enstatite}

Figure 3 shows the liquidus surface of the system diopside - forsterite - enstatite at 5.1 GPa. The eutectic point for the binary system forsterite-enstatite is from Presnall et al. (1998), and the melting temperature of forsterite is from Davis \& England (1964). The boundary line between the primary phase-fields of forsterite and clinopyroxene crosses the forsterite-diopside join at $\mathrm{Fo}_{31} \mathrm{Di}_{69}, 1870^{\circ} \mathrm{C}$. The small differences in temperature among this piercing point, the melting point of pure diopside, the peritectic point on the diopside-enstatite join, and the liq - fo - cpx - opx invariant point indicate a relatively flat liquidus surface for the clinopyroxene primary phase-field. As three-phase triangles always show the same orientation over the entire length of the forsterite-clinopyroxene boundary line (Fig. 4), the temperature minimum on the clinopyroxene liquidus along the diopside-enstatite join does not extend to the forsterite-clinopyroxene boundary line. Run 153 (Table 2) contains all the phases at the invariant point, but the liquid is not sufficiently abundant for a good analysis. Therefore, we have located the composition of the liquidus invariant point $\left(\mathrm{Di}_{43} \mathrm{Fo}_{46} \mathrm{Qtz}_{11}, 1890 \pm\right.$ $20^{\circ} \mathrm{C}$ ) by determining the positions of the three bound-

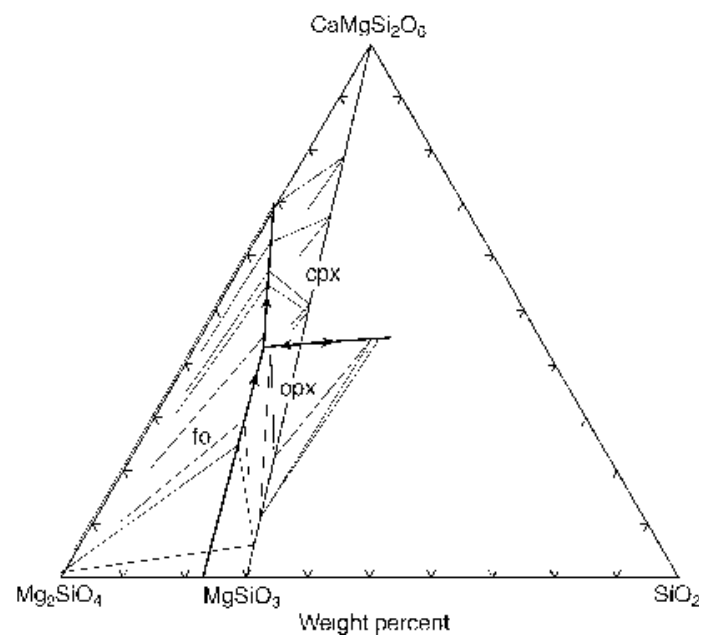

FIG. 4. Three-phase triangles showing the equilibria involving liquid and two crystalline phases. Compositions of liquids along the forsterite-orthopyroxene and forsteriteclinopyroxene boundary lines and compositions of pyroxenes have been moved slightly to the relevant boundary-line or pyroxene join along lines of constant $\mathrm{CaMgSi}_{2} \mathrm{O}_{6}$. Similarly, liquids on the orthopyroxeneclinopyroxene boundary line have been moved slightly along lines of constant $\mathrm{Mg}_{2} \mathrm{SiO}_{4}: \mathrm{SiO}_{2}$ ratio. 
ary lines extending from the invariant point. On the basis of this composition and the compositions of forsterite, orthopyroxene, and clinopyroxene from run 153 , the peritectic-point reaction is $69 \mathrm{opx}+31 \mathrm{liq}=95$ $\mathrm{cpx}+5$ fo.

Liquidus fractionation lines (Presnall 1969) in Figure 5 are based on the three-phase triangles in Figure 4. These lines show liquid paths followed during fractional crystallization for any starting composition in the system. No arrows occur on the boundary line between the orthopyroxene and clinopyroxene primary phase-fields because liquid compositions do not move along this line during fractional crystallization.

The effect of increasing pressure on liquidus boundary lines is shown in Figure 6. Our data extend the lower-pressure data indicating that increasing pressure causes the forsterite field to contract relative to the clinopyroxene and orthopyroxene fields, and causes the orthopyroxene field to contract relative to the clinopyroxene field.

\section{Modeling of Mantle Melting}

At low to moderate pressures, low-melt-fraction magmas generated from mantle lherzolite are in equilibrium with both clinopyroxene and orthopyroxene. Both pyroxenes are present at the solidus. Takahashi (1986) was the first to show that at higher pressures, orthopyroxene disappears from the solidus, and Walter (1998) showed that for a fertile lherzolite, this disappearance occurs at about $3.3 \mathrm{GPa}$. In addition, he found that with increasing degrees of isobaric melting at higher

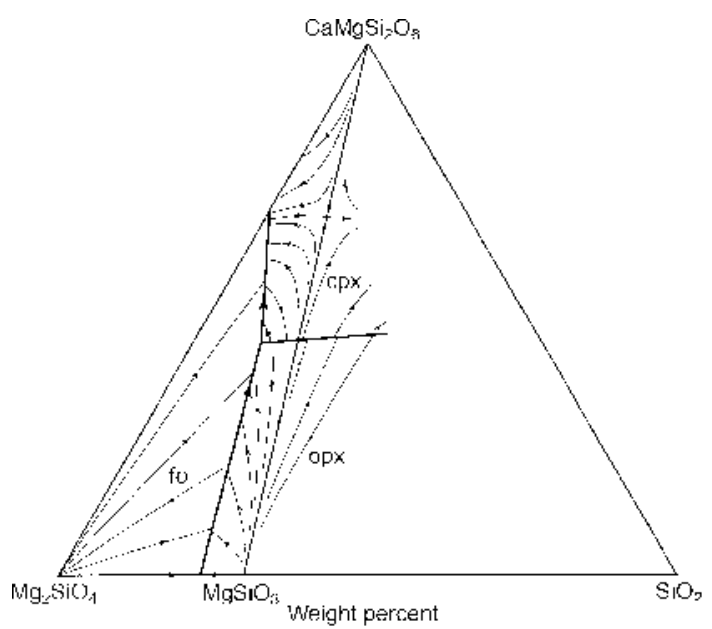

FIG. 5. Liquidus fractionation lines. Arrows show directions of movement of liquids during perfect fractional crystallization.

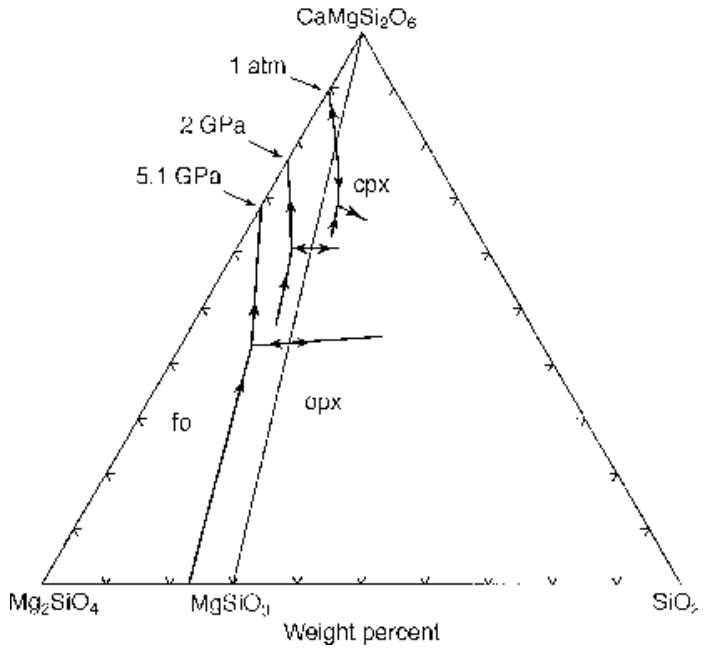

FIG. 6. Comparison of liquidus boundary lines as a function of pressure. Boundary lines at 1 atm are from Bowen (1914), Schairer \& Yoder (1962), Kushiro \& Schairer (1963), and Longhi \& Boudreau (1980). Those at $2 \mathrm{GPa}$ are from Kushiro (1969). For simplicity, all of the Ca-poor pyroxene phases at 1 atm (Kushiro 1972a, Longhi \& Boudreau 1980, Carlson 1988) and 2 GPa (Kushiro 1969) are included as part of the opx field.

pressures, orthopyroxene reappears and then disappears again at still higher degrees of melting. Milholland \& Presnall (1998) showed that at similar pressures, the same melting behavior occurs for model lherzolite in the system $\mathrm{CaO}-\mathrm{MgO}-\mathrm{Al}_{2} \mathrm{O}_{3}-\mathrm{SiO}_{2}$, and these features were subsequently also discussed by Herzberg \& O'Hara (1998). Here, we show that in the ternary system diopside - forsterite - enstatite, the quantitative details of this melting sequence closely match those for the natural peridotite studied by Walter (1998) and provide a simple and rigorous understanding of this seemingly enigmatic behavior.

In Figure 7a, it can be seen that at $2 \mathrm{GPa}$, orthopyroxene, clinopyroxene, and olivine occur at the solidus for the model mantle composition M. On heating, $21 \%$ of liquid e is produced as the average composition of the crystals moves from $\mathrm{M}$ to $\mathrm{n}$. At $\mathrm{n}$, clinopyroxene is entirely consumed. Further heating produces liquids with compositions from e to $g$ as the crystal path is extended to $\mathrm{s}$, where orthopyroxene is entirely consumed. The remaining liquids, which range from $\mathrm{g}$ to $\mathrm{M}$, are in equilibrium only with forsterite, which changes very slightly in composition from $\mathrm{s}$ to $\mathrm{Mg}_{2} \mathrm{SiO}_{4}$. Table 3 lists these changes and the melt proportions at each stage. Also shown in Table 3 is a comparison with the melting behavior of peridotite KR4003, as extrapolated from the data of Walter (1998) at 3-7 GPa. The identical sequence of phase assemblages and the closely similar 


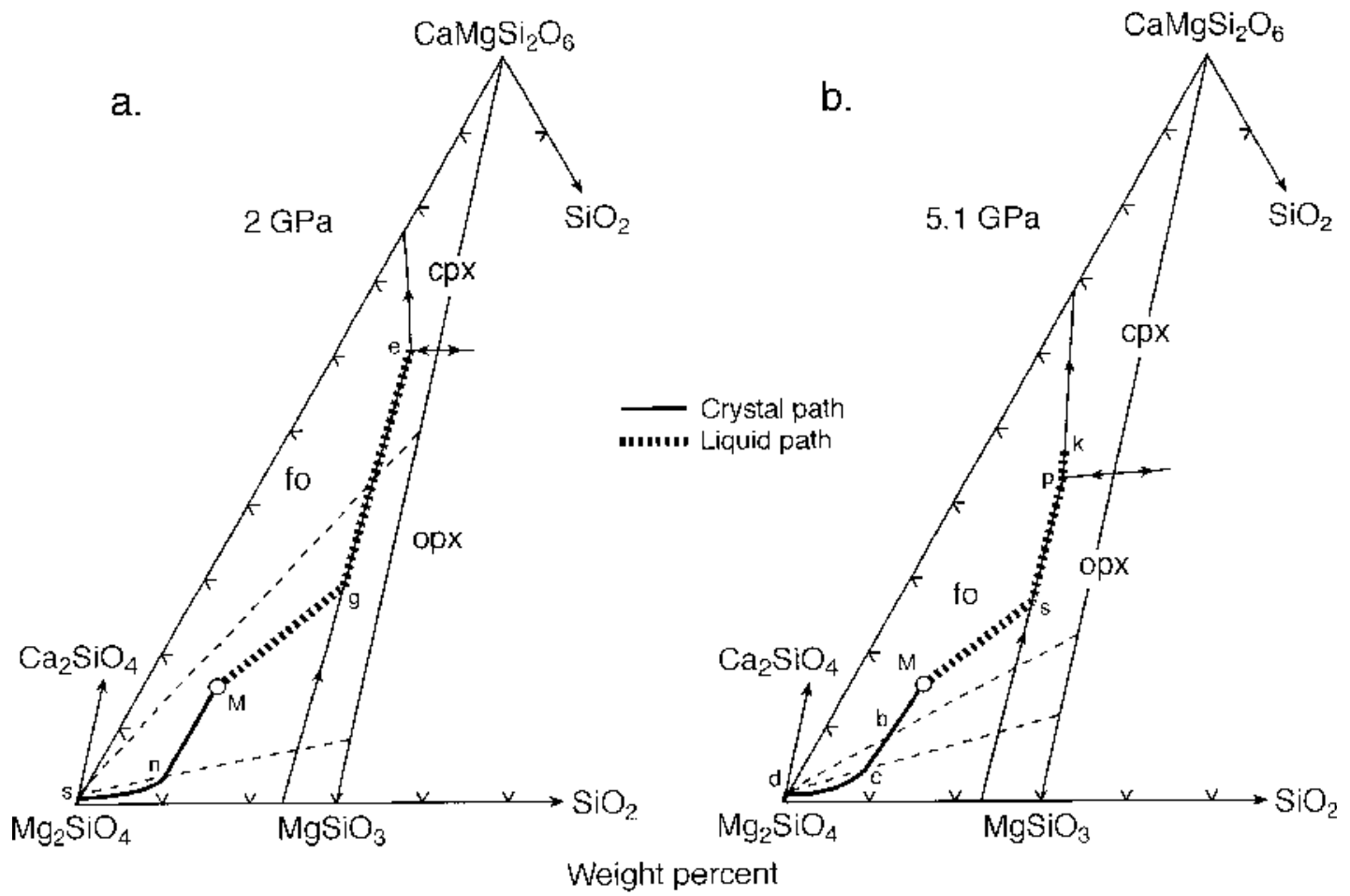

FIG. 7. Equilibrium melting of model lherzolite $\mathrm{M}$ at (a) $2 \mathrm{GPa}$ and (b) $5.1 \mathrm{GPa}$. Dashed lines and liquidus boundary lines are the same as in Figures 3 and 6. The location of the eutectic between forsterite and enstatite at $2 \mathrm{GPa}$ is from Presnall et al. (1998). For simplicity, the small field of pigeonitic clinopyroxene of Kushiro (1969) at $2 \mathrm{GPa}$ is omitted and included as part of the opx field. Because this field is small and pigeonitic clinopyroxene is close in composition to enstatite, the melting behavior is affected only slightly by this simplification.

TAELE 3. EOUILIBRIAM MELITIG OF MODET, AND NATURAL PERIDOTITE $M T$ TPa
Di kn tin fystem

\%olting Phases

(1-21

21-53

53100

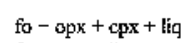

fo $-s p k+c p x+1$

lo, licy
Peridatitu: KR4/07\%

\begin{tabular}{|c|c|}
\hline \% Fielting & Phankes \\
\hline $0 \cdot 17$ & $\mathrm{al}-\mathrm{cps}+\mathrm{apx}-\mathrm{diq}$ \\
\hline $\begin{array}{l}17-45 \\
49.100\end{array}$ & ol - opx + liq \\
\hline
\end{tabular}

Extrajolaced tourl dala or Waller (159B) at 3-7 GPa

melting proportions at each stage show that at this pressure, the ternary system diopside - forsterite - enstatite models the melting behavior of natural peridotite very well.

At $5.1 \mathrm{GPa}$, the equilibrium melting behavior is quite different (Fig. 7b). The crystalline assemblage at the solidus is forsterite + clinopyroxene. Orthopyroxene is absent because of the marked increase in the proportion of $\mathrm{MgSiO}_{3}$ in clinopyroxene at this pressure. The first liquid is produced on the forsterite-clinopyroxene boundary line at $\mathrm{k}$, and increasing temperature drives the bulk composition of the crystalline residue along the crystal path to $b$, where orthopyroxene first appears. Further heating produces liquids at the peritectic $p$, and the bulk composition of the residue is driven toward c as the proportion of orthopyroxene increases. At c, clinopyroxene disappears and leaves a residue consisting of orthopyroxene and forsterite. As temperature increases further, the liquid moves to $s$ as the average composition of the crystals moves to $\mathrm{d}$. The proportion of orthopyroxene in the residue decreases during this stage of melting and reaches zero at $d$. The final stage of melting produces liquids from $\mathrm{s}$ to $\mathrm{M}$ and occurs in the presence only of forsterite, which changes slightly in composition from $\mathrm{d}$ to pure $\mathrm{Mg}_{2} \mathrm{SiO}_{4}$.

Table 4 shows a comparison of the melting behavior of the peridotite used by Walter (1998) and the ternary model peridotite at $5.1 \mathrm{GPa}$. Except for the presence of garnet (shown in parentheses) in the natural composition, the sequence of phase appearance and disappearance is identical, and the melt proportions are again 
TABLE 4. EQULERRTM MELTING OF MOTPEL AVD VAT LIR.AI. PIRTDOTITF. AT S.l G GPa

\begin{tabular}{|c|c|c|c|}
\hline \multicolumn{2}{|c|}{ Di-Tu-F.n syseteri } & \multicolumn{2}{|c|}{ Petidolite KRA0OS (Wralter lygs) } \\
\hline$\%$ Melting & Phases & W Yrelting & Phajes: \\
\hline 1) 23 & 5o 1 cpx $;$ liq & $0-22$ & $o l+c p x-i n(-s t)$ \\
\hline $23-30$ & fo $+\cos x-\cos x+\operatorname{lig}$ & $22-35$ & of $+\mathrm{cpx}-\mathrm{spr}+\mathrm{liq}(+\mathrm{st})$ \\
\hline $.30-5.5$ & $t^{2} v+c p x-1 \cos$ & 3541 & $a t+o p x-\operatorname{liq}(-s)$ \\
\hline & & $41-54$ & $\mathrm{al}+\mathrm{aps}+\mathrm{r} \operatorname{liq}$ \\
\hline $55-100$ & fo I lig & $54-100$ & of + liq \\
\hline
\end{tabular}

remarkably similar. Thus, although the presence of garnet slightly degrades the comparison with natural peridotite melting, it can be seen that other aspects of the melting behavior of the ternary system are essentially identical to those of the natural composition.

There is another feature of the diopside - forsterite enstatite system that makes it a useful model of melting behavior in the mantle. Figure 6 shows that the composition of the peritectic becomes increasingly enriched in $\mathrm{MgO}$ and depleted in $\mathrm{SiO}_{2}$ as pressure increases. This feature is well known from previous studies at lower pressures, and the present data at 5.1 GPa shows that the trend continues at higher pressures. It is important to note, however, that compositions of initial melts do not lie on the $\mathrm{SiO}_{2}$-poor side of the forsterite-diopside join and therefore remain in the tholeiitic portion of the basalt tetrahedron of Yoder \& Tilley (1962) at all pressures at least up to $5 \mathrm{GPa}$. The same thing occurs in the four-component system $\mathrm{CaO}-\mathrm{MgO}-\mathrm{Al}_{2} \mathrm{O}_{3}-\mathrm{SiO}_{2}$ (CMAS) (Presnall et al. 1978, 1979, Weng \& Presnall 1995, Gudfinnsson \& Presnall 1996, Milholland \& Presnall 1998, Herzberg \& Zhang 1998, Presnall 1999, Liu \& Presnall 2000). However, when $\mathrm{Na}_{2} \mathrm{O}$ is added to the CMAS system, initial melts produced at pressures from about 1.2 to $3.5 \mathrm{GPa}$ lie on the alkaline side of the olivine - diopside - plagioclase plane (Walter \& Presnall 1994). Thus although the ternary system elegantly models many aspects of peridotite melting, even in a semi-quantitative way, other aspects are not, and caution is required.

\section{ACKNOWLEDGEMENTS}

It is a great pleasure to be able to contribute to this collection of papers in honor of Pete Roeder. For one of us (DCP), the memory of our time together at Penn State is especially warm. Valuable journal reviews were given by D. Canil, C. Herzberg, and R.F. Martin. Financial support was provided by National Science Foundation Grants EAR-9219159 and EAR-9725900 to Presnall.

\section{REFERENCES}

Bohlen, S.R. \& Boettcher, A.L. (1982): The quartz $\rightleftharpoons$ coesite transformation: a precise determination and the effects of other components. J. Geophys. Res. 87, 7073-7078.

BoweN, N.L. (1914): The ternary system: diopside - forsterite - silica. Am. J. Sci. 188, 207-264.

(1928): The Evolution of the Igneous Rocks. Princeton University Press, Princeton, New Jersey.

Boyd, F.R. (1987): High- and low-temperature garnet peridotite xenoliths and their possible relation to the lithosphere-asthenosphere boundary beneath southern Africa. In Mantle Xenoliths (P.H. Nixon, ed.). John Wiley \& Sons, New York, N.Y. (403-412).

\& England, J.L. (1963): Effect of pressure on the melting of diopside, $\mathrm{CaMgSi}_{2} \mathrm{O}_{6}$, and albite, $\mathrm{NaAlSi}_{3} \mathrm{O}_{8}$, in the range up to 50 kilobars. J. Geophys. Res. 68, 311-323.

\& DAvis, B.T.C. (1964): Effects of pressure on the melting and polymorphism of enstatite, $\mathrm{MgSiO}_{3}$. J. Geophys. Res. 69, 2101-2109.

\& Mertzman, S.A. (1987): Composition and structure of the Kaapvaal lithosphere, southern Africa. In Magmatic Processes: Physicochemical Principles (B. Mysen, ed.). Geochem. Soc., Spec. Publ. 1, 13-24.

CANIL, D. (1992): Orthopyroxene stability along the peridotite solidus and the origin of cratonic lithosphere beneath southern Africa. Earth Planet. Sci. Lett. 111, 83-95.

Carlson, W.D. (1988): Subsolidus phase equilibria on the forsterite-saturated join $\mathrm{Mg}_{2} \mathrm{Si}_{2} \mathrm{O}_{6}-\mathrm{CaMgSi}_{2} \mathrm{O}_{6}$ at atmospheric pressure. Am. Mineral. 73, 232-241.

CARTer, J.L. (1970): Mineralogy and chemistry of the Earth's upper mantle based on the partial fusion - partial crystallization model. Geol. Soc. Am., Bull. 81, 2021-2034.

Dalton, J.A. \& Presnall, D.C. (1997): No liquid immiscibility in the system $\mathrm{MgSiO}_{3}-\mathrm{SiO}_{2}$ at $5.0 \mathrm{GPa}$. Geochim. Cosmochim. Acta 61, 2367-2373.

$\&$ (1998a): Carbonatitic melts along the solidus of model lherzolite in the system $\mathrm{CaO}-\mathrm{MgO}-$ $\mathrm{Al}_{2} \mathrm{O}_{3}-\mathrm{SiO}_{2}-\mathrm{CO}_{2}$ from 3 to $7 \mathrm{GPa}$. Contrib. Mineral Petrol. 131, 123-135.

$\&$

(1998b): The continuum of primary carbonatitic-kimberlitic melt compositions in equilibrium with lherzolite: data from the system $\mathrm{CaO}-\mathrm{MgO}-\mathrm{Al}_{2} \mathrm{O}_{3}-$ $\mathrm{SiO}_{2}-\mathrm{CO}_{2}$ at 6 GPa. J. Petrol. 39, 1953-1964.

DAvis, B.T.C. \& Boyd, F.R. (1966): The join $\mathrm{Mg}_{2} \mathrm{Si}_{2} \mathrm{O}_{6}-$ $\mathrm{CaMgSi}_{2} \mathrm{O}_{6}$ at 30 kilobars pressure and its application to pyroxenes from kimberlites. J. Geophys. Res. 71, 35673576. 
\& ENGLAND, J.L. (1964): The melting of forsterite up to 50 kilobars. J. Geophys. Res. 69, 1113-1116.

DiCK, H.J.B. \& FISHER, R.L. (1984): Mineralogical studies of the residues of mantle melting: abyssal and alpine-type peridotites. In Kimberlites II: The Mantle and Crust-Mantle Relationships (J. Kornprobst, ed.). Elsevier, Amsterdam, The Netherlands (295-308).

\& BRYAN, W.B. (1984): Mineralogical variability of the uppermost mantle along mid-ocean ridges. Earth Planet. Sci. Lett. 69, 88-106.

GASPARIK, T. (1990): A thermodynamic model for the enstatite-diopside join. Am. Mineral. 75, 1080-1091.

(1996): Melting experiments on the enstatitediopside join at 70-224 kbar, including the melting of diopside. Contrib. Mineral. Petrol. 124, 139-153.

Gudfinnsson, G. \& Presnall, D.C. (1996): Melting relations of model lherzolite in the system $\mathrm{CaO}-\mathrm{MgO}-\mathrm{Al}_{2} \mathrm{O}_{3}-\mathrm{SiO}_{2}$ at $2.4-3.4 \mathrm{GPa}$ and the generation of komatiites. $J$. Geophys. Res. 101, 27,701-27,709.

Hemingway, B.S., Bohlen, S.R., Hankins, W.B., Westrum, E.F., JR. \& KusKov, O.L. (1998): Heat capacity and thermodynamic properties for coesite and jadeite, reexamination of the quartz-coesite equilibrium boundary. Am. Mineral. 83, 409-418.

Herzberg, C. (1992): Depth and degree of melting of komatiites. J. Geophys. Res. 97, 4,521-4,540.

\& O’HARA, M.J. (1998): Phase equilibrium constraints on the origin of basalts, picrites, and komatiites. Earth-Sci. Rev. 44, 39-79.

\& ZHANG, JIANZHONG (1998): Melting experiments in the systems $\mathrm{CaO}-\mathrm{MgO}-\mathrm{Al}_{2} \mathrm{O}_{3}-\mathrm{SiO}_{2}$ and $\mathrm{MgO}-\mathrm{SiO}_{2}$ at 3 to $15 \mathrm{GPa}$. Am. Mineral. 83, 491-500.

KushiRo, I. (1968): Compositions of magmas formed by partial zone melting of the Earth's upper mantle. J. Geophys. Res. 73, 619-634.

(1969): The system forsterite - diopside - silica with and without water at high pressures. Am. J. Sci. 267-A, 269294.

(1972a): Determination of liquidus relations in synthetic silicate systems with electron probe analysis: the system forsterite - diopside - silica at 1 atmosphere. Am. Mineral. 57, 1260-1271.

(1972b): Effect of water on the composition of magmas formed at high pressures. J. Petrol. 13, 311-334.

(1975): On the nature of silicate melt and its significance in magma genesis: regularities in the shift of the liquidus boundaries involving olivine, pyroxene, and silica minerals. Am. J. Sci. 275, 411-431.
\& SCHAIRER, J.F. (1963): New data on the system diopside - forsterite - silica. Carnegie Inst. Wash., Year Book 62, 95-103.

LiU, Teh-Ching \& PREsnall, D.C. (2000): Liquidus phase relations in the system $\mathrm{CaO}-\mathrm{MgO}-\mathrm{Al}_{2} \mathrm{O}_{3}-\mathrm{SiO}_{2}$ at $2.0 \mathrm{GPa}$ : applications to basalt fractionation, eclogites, and igneous sapphirine. J. Petrol. 41, 3-20.

Longhi, J. \& Boudreau, A.E. (1980): The orthoenstatite liquidus field in the system forsterite - diopside - silica at one atmosphere. Am. Mineral. 65, 563-573.

Milholland, C.S. \& Presnall, D.C. (1998): Liquidus phase relations in the $\mathrm{CaO}-\mathrm{MgO}-\mathrm{Al}_{2} \mathrm{O}_{3}-\mathrm{SiO}_{2}$ system at $3.0 \mathrm{GPa}$ : the aluminous pyroxene thermal divide and high-pressure fractionation of picritic and komatiitic magmas. J. Petrol. 39, 3-27.

Parman, S.W., Dann, J.C., Grove, T.L. \& De Wit, M.J. (1997): Emplacement conditions of komatiite magmas from the $3.49 \mathrm{Ga}$ Komati Formation, Barberton greenstone belt, South Africa. Earth Planet. Sci. Lett. 150, 303-323.

PRESNALL, D.C. (1969): The geometrical analysis of partial fusion. Am. J. Sci. 267, 1178-1194.

(1999): Effect of pressure on the fractional crystallization of basaltic magma. In Mantle Petrology: Field Observations and High Pressure Experimentation (Y. Fei, C.M. Bertka \& B.O. Mysen, eds.). Geochem. Soc., Spec. Publ. 6, 209-224.

BRENNER, N.L. \& O'DonNell, T.H. (1973): Drift of $\mathrm{Pt} / \mathrm{Pt} 10 \mathrm{Rh}$ and $\mathrm{W} 3 \mathrm{Re} / \mathrm{W} 25 \mathrm{Re}$ thermocouples in single stage piston-cylinder apparatus. Am. Mineral. 58, 771-777.

Dixon, J.R., O’Donnell, T.H. \& Dixon, S.A. (1979): Generation of mid-ocean ridge tholeiites. J. Petrol. 20, 3-35.

DiXon, S.A., Dixon, J.R., O'DONNELl, T.H., BRENNER, N.L., Schrock, R.L. \& Dycus, D.W. (1978): Liquidus phase relations on the join diopside - forsterite - anorthite from $1 \mathrm{~atm}$ to $20 \mathrm{kbar}$ : their bearing on the generation and crystallization of basaltic magma. Contrib. Mineral. Petrol. 66, 203-220.

\& GASPARIK, T. (1990): Melting of enstatite $\left(\mathrm{MgSiO}_{3}\right)$ from 10 to $16.5 \mathrm{GPa}$ and the forsterite $\left(\mathrm{Mg}_{2} \mathrm{SiO}_{4}\right)$ - majorite $\left(\mathrm{MgSiO}_{3}\right)$ eutectic at $16.5 \mathrm{GPa}$ : implications for the origin of the mantle. J. Geophys. Res. 95, 15,771-15,777.

Weng, Yi-Hua, Milholland, C.S. \& Walter, M.J. (1998): Liquidus phase relations in the system MgO$\mathrm{MgSiO}_{3}$ at pressures up to $25 \mathrm{GPa}$ - constraints on crystallization of a molten Hadean mantle. Phys. Earth Planet. Int. 107, 83-95.

SCARFE, C.M. \& TAKahashi, E. (1986): Melting of garnet peridotite to $13 \mathrm{GPa}$ and the early history of the upper mantle. Nature 322, 354-356. 
SCHAIRER, J.F. \& Yoder, H.S., JR. (1962): The system diopside - enstatite - silica. Carnegie Inst. Wash., Year Book 61, 75-82.

Susaki, J., Akaogi, M., Akimoto, S. \& Shimomura, O. (1985): Garnet-perovskite transformation in $\mathrm{CaGeO}_{3}$ : in-situ X-ray measurements using synchrotron radiation. Geophys. Res. Lett. 12, 729-732.

TAKAHASHI, E. (1986): Melting of a dry peridotite KLB-1 up to $14 \mathrm{GPa}$ : implications on the origin of peridotitic upper mantle. J. Geophys. Res. 91, 9367-9382.

WALTER, M.J. (1998): Melting of garnet peridotite and the origin of komatiite and depleted lithosphere. J. Petrol.39, 29-60.

\& Presnall, D.C. (1994): Melting behavior of simplified lherzolite in the system $\mathrm{CaO}-\mathrm{MgO}-\mathrm{Al}_{2} \mathrm{O}_{3}-\mathrm{SiO}_{2}-$ $\mathrm{Na}_{2} \mathrm{O}$ from 7 to 35 kbar. J. Petrol. 35, 329-359.
Weng, Yi-Hua \& Presnall, D.C. (1995): Constraints on the depth of origin of komatiites based on melting relations in the system $\mathrm{CaO}-\mathrm{MgO}-\mathrm{Al}_{2} \mathrm{O}_{3}-\mathrm{SiO}_{2}$ at $5 \mathrm{GPa}$. Trans. Am. Geophys. Union (Eos) 76, F696-F697 (abstr.).

Williams, D.W. \& KenNEDY, G.C. (1969): Melting curve of diopside to 50 kilobars. J. Geophys. Res. 74, 4359-4366.

Yoder, H.S., JR. \& TiLley, C.E. (1962): Origin of basalt magmas: an experimental study of natural and synthetic rock systems. J. Petrol. 3, 342-532.

Received October 22, 1999, revised manuscript accepted October 31, 2000. 